\title{
The stimulatory effects of L-tryptophan and plant growth promoting rhizobacteria (PGPR) on soil health and physiology of wheat
}

\author{
T. Ul Hassan ${ }^{1}$, A. Bano ${ }^{1 *}$ \\ ${ }^{1}$ Department of Plant Sciences Quiad-i-Azam University, Islamabad 45320, Pakistan. *Corresponding author: \\ banoasghari@gmail.com
}

\begin{abstract}
During the present study, Pseudomonas moraviensis and Bacillus cereus, were isolated from rhizosphere soil of halophytic weed (cenchrus ciliaris L.) of Khewra salt range, and used as bioinoculants. The plant growth promoting rhizobacteria (PGPR) were applied to wheat (Triticum aestivum) by seeds soaking, and aqueous solution of tryptophan was added to the rhizosphere soil at $1 \mathrm{ug} / \mathrm{L}$, after seed germination. Experiment was conducted at Quaid-e-Azam University Islamabad both in pots (filled with sterilized soil) under axenic condition and in field under natural condition, for two consecutive years. The inoculation of Pseudomonas moraviensis and Bacillus cereus, significantly increased the organic matter, $\mathrm{P}, \mathrm{K}, \mathrm{Ca}$, and $\mathrm{NO}_{3}-\mathrm{N}$ availability of soil. The inoculation of these PGPR positively enhanced growth and physiology of treated plants, and this affect was further augmented in the presence of tryptophan. Addition of tryptophan with Pseudomonas moraviensis and Bacillus cereus increased the fresh weight, proline contents and activities of antioxidant enzymes significantly over control. Added tryptophan with both PGPR, improved the number of plants at yield and seeds establishment by improving number of seeds/spike and spike length. Effects of PGPR inoculation alone and with tryptophan were more pronounced in pots grown plants. It is inferred from the results, that tryptophan addition is a competent source for increasing potential of PGPR, thereby improving wheat growth, and physiology.
\end{abstract}

Keywords: PGPR and wheat, Bacillus cereus, Pseudomonas, antioxidants, L-tryptophan

\section{Introduction}

One of the most important aspects of PGPR is phytohormones production for improving growth and physiology of corps. Among these phytohormones, indoleacetic acid (IAA) commonly known as auxin is of prime importance. Agriculturally important PGPR are screened out on the basis of their potential to produce IAA. The production of auxin depends upon response of plant seedling and types of applied microbial inoculants. Microbial strains having ability to produce higher and lower amount of IAA, or indoleacetamide (IAM) have resulted increase growth and yield of wheat (Tsavkelova et al., 2007). L-tryptophan, the precursor of IAA, is naturally present in root exudates of plants (Villareal et al., 2012). It is also synthesized by hydrolysis of proteins of dead cells (Patten and Glick 1996), and 
is converted into indole acetic acid by the activity of plant growth promoting rhizobacteria (Sasirekha et al.,2012).

Application of L-tryptophan in soil has proved very fruitful for increasing growth of many vegetables as well as crops like chickpea (Abbas et al., 2013) and wheat (Mohite, 2013). It is believed that about $80 \%$ of bacterial isolates from rhizosphere soil are capable of synthesizing IAA (Idris et al., 2004)

Microbial bioinoculants have ability to improve the availability of soil nutrients and modulation of phytohormones (Hayyat et al., 2013). Auxin biosynthesis in bacteria is affected by a number of factors, including environmental stress, $\mathrm{pH}$, osmotic and matrix stresses, carbon starvation, and the composition of the root exudates.

Bacillus cereus has the potential to increase the yield, growth and nutrition of broccoli plant under organic growing conditions. It is efficient phosphate solubilizer and a bio pesticide against the fungal pathogens that attack the plants during the nodulation stage of Pigeon Pea (Rani et al., 2011). The use and effectiveness of Bacillus cereus as PGPR has previously been proved (Zhao et al., 2011).

Pseudomonas spp and their consortium with other microbial strains improved growth and yield of wheat (Rosas et al., 2009). Similarly, inoculation of Pseudomonas fluorescence increased roots and shoots mass in sugarcane (Mehnaz et al., 2009). Pseudomonas aeruginosa has been used for promoting growth of cow pea (Sasirekha et al., 2012). Pseudomonas inoculation on winter wheat depends upon development phase of wheat as well as on population size of Pseudomonas (Wachowska et al., 2006).

This paper reports the effects of tryptophan alone and in association with two plant growth promoting bacteria, Bacillus cereus and Pseudomonas moraviensis on the growth and physiology of wheat under pots and field conditions. The work highlights the effectiveness of these PGPR and tryptophan contribution in modulation of nutrient status of soil and their accumulation in the leaves.

\section{Material and Methods}

2.1. Isolation of endophytic microbes and determination of colony forming unit

The Buffle grass (Cenchrus ciliaris L.), a naturally growing halophyte was uprooted when the plants were 13-15 cm high. Roots were washed with tap water followed by washing with autoclaved water. Grinded roots $(1 \mathrm{~g})$ was suspended in $9 \mathrm{ml}$ autoclaved distilled water and an aliquot $(100 \mu \mathrm{l})$ from decimal dilution was used to inoculate LB culture media. The culture plates were incubated for $24-72 \mathrm{~h}$ at $27^{\circ} \mathrm{C}$. The number of viable cell counts at $10^{7}$ dilution were calculated following the formula.

Viable cell count $(\mathrm{CFU} / \mathrm{g})=$ (number of colonies/ volume of inocula) $\mathrm{x}$ dilution factor

a) DNA extraction

Extraction of genomic DNA of bacterial strain was carried out by using the Gen Elute Bacterial Genomic DNA Kit.

b) PCR amplification

The genomic DNA of PGPR was amplified by the method as described by Weisburg (1991). The polymerase chain reaction (PCR) was carried out by using forward (fd1) primer having nucleotide sequence AGAGTTTGATCCTGGCTCAG and reverse (rd1) primer (AAGGAGGTGATCCAGCC). After denaturation at $95{ }^{\circ} \mathrm{C}$ for $2 \mathrm{~min}, 30$ rounds of temperature cycling $\left(94{ }^{\circ} \mathrm{C}\right.$ for $30 \mathrm{sec}, 55^{\circ} \mathrm{C}$ for $30 \mathrm{sec}$ 
and $72{ }^{\circ} \mathrm{C}$ for $2 \mathrm{~min}$ ) were followed by incubation at $72{ }^{\circ} \mathrm{C}$ for $10 \mathrm{~min}$. Then, $5 \mu 1$ of amplified PCR products were electrophoresed on $1.2 \%(\mathrm{w} / \mathrm{v})$ agarose gel, in 1 $\mathrm{X}$ TBE buffer at $80 \mathrm{~V}$ and then stained with ethidium bromide $(0.01 \mathrm{~g} / \mathrm{ml})$. Gel was visualized under UV transilluminator lamp ( S. N. 76S/64069, Bio RAD, Italy) and photographed.

\section{c) Sequencing for $16 \mathrm{~S}$ rRNA}

Sequencing was done using Big Dye terminator cycle sequencing kit v.3.1 (Applied BioSystems, USA) and the sequencing products were resolved on sequencer (ABI 3730 x 1 DNA Analyzer (Applied BioSystems, USA) at the Macrogen, Inc Seoul, Korea. The results were compared at NCBI site using BLAST algorithm (www. ncbi.nlm.nih.gov/BLAST. The isolates were identified as Pseudomonas moraviensis (Accession No. LN714047) and Bacillus cereus (Accession No. LN714048) and data was submitted to gene bank.

d) Plant materials and growth conditions

Seeds of Triticum aestivum L. variety Inqlab 91 were obtained from National Agriculture Research Council Islamabad (NARC) and were grown at Quaid-e-Azam University, Islamabad (maximum average temperature $=$ $21.9^{\circ} \mathrm{C}$, rainfall $=8.98 \mathrm{~mm}$. and relative humidity $=67.16 \%$ ) both in pots under axenic condition (EC $0.30 \mathrm{dSm}^{-}$) and in field under natural condition. For field experiment, field measuring $10 \times 10 \mathrm{~m}^{2}$ was prepared with $36 \mathrm{~cm}$ row to rows distance. Seeds were sown by hand drill method in field soil having silt: clay: sand in 14:11:75. Simultaneously, earthen pots measuring $17 \times 20 \mathrm{~cm}^{2}$, containing $8 \mathrm{Kg}$ soil/ pot were filled with autoclaved soil and mixed with sand in 3:1 ratio. No chemical or organic fertilizer was added in the soils. In each pot 10-15 seeds were sown and five plants/ pots were maintained till maturity.
Treatments include inoculation of Pseudomonas moraviensis and Bacillus cereus with and without addition of tryptophan. Uninoculated plants were taken as control while tryptophan without any PGPR was also applied. Plants sampling was done at early vegetative stage (57 DAS) for physiological parameters and at maturity (159 DAS) for yield parameters.

Prior to sowing seeds were surface sterilized with $70 \%$ ethanol for $5 \mathrm{~min}$ followed by soaking the seeds in $10 \%$ chlorox and successively washed with autoclave distilled water. The sterilized seeds were soaked in $7 \mathrm{~d}$ old microbial cultures having $10^{6} \mathrm{cell} /$ $\mathrm{ml}$. After shade drying seeds were sown under field condition. The RCBD design was used in field while CRD was followed for pots grown plants. After $7 d$ of germination of seeds aqueous solution of L-tryptophan $1 \mathrm{ug} / \mathrm{L}$ was applied in rooting zone of seedlings.

e) Sampling and chemical analysis of rhizosphere soil

The rhizospheric soil samples of wheat were collected at early vegetative stage (57 DAS) below $7-10 \mathrm{~cm}$ from surface. Soil samples were homogenized, and sieved through $2 \mathrm{~mm}$ sieve and processed for the isolation of rhizobacteria and determination of physico-chemical properties.

f) Soil organic matter

Soil organic matter was determined by method of Walkley and Black, 1934.

g) Nitrate-N $\left(\mathrm{NO}_{3}-\mathrm{N}\right)$ and Phosphorus $(\mathrm{P})$

Nitrate-N $\left(\mathrm{NO}_{3}-\mathrm{N}\right)$ and Phosphorus (P) were extracted from rhizosphere soil following the method of Reitemeier (1943). 
h) Chlorophyll contents of leaves

The chlorophyll contents of leaves were determined by chlorophyll meter (SPAD 502 plus)

\subsection{Proline content}

Proline contents were measured by the method of Bates et al., (1973) and activity for peroxidase was measured by method of Vetter et al., (1958). Fresh leaves $(5 \mathrm{~g})$ were homogenized with $15 \mathrm{ml}$ of $0.05 \mathrm{~N}$ phosphate buffer ( $\mathrm{pH} 7.0$ ) containing $10 \%$ polyvinyl poly pyrrolidone and $0.1 \mathrm{M}$ Ethylene diamine tetra acetate (EDTA).

\subsection{Assay for Peroxidase activity (POD)}

The assay mixture contained $0.1 \mathrm{ml}$ enzyme extract, $1.35 \mathrm{ml}$ of $100 \mathrm{mM}$ MES buffer ( $\mathrm{pH} 5.5$ ), $0.05 \% \mathrm{H}_{2} \mathrm{O}_{2}$ and $0.1 \%$ phenylenediamine. Change in absorbance was recorded at $485 \mathrm{~nm}$ with spectrophotometer (UV-120-01, Shimadzu). The activity of POD was presented as $\triangle$ OD $485 \mathrm{nmmin}^{-1} \mathrm{mg}^{-1}$.

\subsection{Assay for superoxide dismutase activity (SOD)}

SOD activity was determined by measuring inhibition of photochemical reduction of nitrobluetetrazolium (NBT) using method of Beauchamp and Fridovich (1971).

\subsection{Statistical analyses}

The statistical analyses of the data were conducted using analysis of variance (ANOVA) in Statistix program, version 8.1. In field experiments Randomize Block Design (RCBD) was followed and for pots experiment Complete Randomized Design (CRD) was applied. Mean values were separated $(p=0.05)$ and represented by different letters both in tables and figures along with \pm standard error.

\section{Results and Discussion}

The endophytic bacteria, residing in the roots of plants, are the tools of extensive studies. The application of these endophytes as Plant growth promoting bacteria (PGPB) and their role in crop improvement is widely documented. Bacillus cereus and Pseudomonas moraviensis has also been isolated and tested for their growth promoting potential previously (Zhao et al., 2011; Yadav et al., 2013).

\subsection{Soil nutrients}

Inoculation of Bacillus cereus and Pseudomonas moraviensis, exhibited $35 \%$ higher soil organic matter in rizosphere of pots grown wheat plants, and a further $25 \%$ increase was observed both in pot and field grown plants, when tryptophan was added.

The PGPR bioinoculants increased the availability of phosphorous and enriched the rhizophere with $\mathrm{NO}_{3}-\mathrm{N}$. Increase in $\mathrm{NO}_{3}-\mathrm{N}$ (Table 1) was $24 \%$ and $45 \%$ when Pseudomonas moraviensis or Bacillus cereus were applied separately in fields and plant grown plants respectively. The PGPR resulted further $24-30 \%$ increase in $\mathrm{NO}_{3}-\mathrm{N}$ in the presence of tryptophan. Increase in $\mathrm{P}$ contents of rhizosphere soil was $25 \%$ and $16 \%$ higher over control in pots and field grown plants. Tryptophan addition further increased P contents of pots grown plants by $28 \%$. Similarly, tryptophan addition with PGPR enhanced the $\mathrm{K}$ contents of rhizosphere soil by $35 \%$ over control, both in pots and field grown plants. PGPR application improved $\mathrm{Ca}$ and $\mathrm{Mg}$ contents of rhizosphere soil of wheat by $20 \%$ over control (Table 1). Application of tryptophan with PGPR showed further $10 \%$ increase in pots and field grown plants. Similarly, increase in 
Mg contents was $16 \%$ higher in pots and $40 \%$ in field when PGPR were added with tryptophan.

The contribution of PGPR in improving plant growth is directly correlated with the mechanism by which they enhance the availability of nutrients $(\mathrm{N}, \mathrm{P}$ and $\mathrm{K})$ (Shaharoona et al., 2008). The increased phosphorus, $\mathrm{NO}_{3}-\mathrm{N}$ contents in treated soil, with tryptophan and PGPR might be attributed to phosphate solublization and N-fixing ability of Pseudomonas moraviensis and Bacillus cereus (Schoebitz et al 2013; Yadav et al., 2013). Tryptophan addition to soil stimulated the ability of applied PGPR in improving $\mathrm{N}, \mathrm{P}, \mathrm{K}$, and other nutrients. Improvement in $\mathrm{K}, \mathrm{Ca}, \mathrm{Mg}$, and $\mathrm{Fe}$ attributed the ability of PGPR in balancing nutrients. The increase in nutrients uptake of PGPR treated plants is in agreement with previous findings of Minaxi et al., (2013). (Table 2)

\subsection{Leaves nutrients}

Table 1. Effects of PGPR on organic matter (\%), macro and micronutrients (mg/Kg) of rhizosphere soil. Measurements were made at 57 DAS (2-3 leaf stage). Values are mean of four replicates.

\begin{tabular}{|c|c|c|c|c|c|c|c|c|c|c|c|c|}
\hline & \multicolumn{2}{|c|}{ O.M } & \multicolumn{2}{|c|}{ P } & \multicolumn{2}{|c|}{$\mathrm{NO}_{-3-\mathrm{N}}$} & \multicolumn{2}{|c|}{$\mathbf{K}^{+}$} & \multicolumn{2}{|c|}{$\mathrm{Ca}^{+}$} & \multicolumn{2}{|c|}{$\mathrm{Mg}^{+}$} \\
\hline \multicolumn{3}{|r|}{ (\%) } & \multicolumn{10}{|c|}{$(\mathrm{mg} / \mathrm{kg})$} \\
\hline Treatments & Field & Pots & Field & Pots & Field & Pots & Field & Pots & Field & Pots & Field & Pots \\
\hline \multirow[t]{2}{*}{ control* } & $0.567 \mathrm{e}$ & $0.45 \mathrm{~d}$ & $4.71 \mathrm{~d}$ & $0.561 \mathrm{c}$ & $16.43 \mathrm{c}$ & $14.42 \mathrm{e}$ & $77.41 \mathrm{f}$ & $105.2 \mathrm{lc}$ & $27.5 \mathrm{c}$ & $32.89 \mathrm{~F}$ & $4.56 \mathrm{e}$ & $7.666 \mathrm{e}$ \\
\hline & $( \pm 0.08)$ & $( \pm 0.08)$ & $( \pm 0.22)$ & $( \pm 0.08)$ & $( \pm 0.44)$ & $( \pm 0.23)$ & $( \pm 2.90)$ & $( \pm 2.23)$ & $( \pm 0.76)$ & $( \pm 0.76)$ & $( \pm 0.21)$ & $( \pm 0.89)$ \\
\hline \multirow[t]{2}{*}{ P.moraviensis } & $0.687 \mathrm{~b}$ & $0.62 \mathrm{c}$ & $5.89 \mathrm{~b}$ & $0.623 \mathrm{~b}$ & $21.75 \mathrm{c}$ & $21.12 \mathrm{~b}$ & $88.8 \mathrm{c}$ & $111.54 \mathrm{c}$ & $32.01 \mathrm{ab}$ & $40.22 \mathrm{c}$ & $5.65 \mathrm{c}$ & $9.67 \mathrm{~d}$ \\
\hline & $( \pm 0.02)$ & $( \pm 0.06)$ & $( \pm 0.12)$ & $( \pm 0.02)$ & $( \pm 0.76)$ & $( \pm 0.39)$ & $( \pm 3.98)$ & $( \pm 1.21)$ & $( \pm 0.77)$ & $( \pm 1.11)$ & $( \pm 0.12)$ & $( \pm 0.49)$ \\
\hline \multirow[t]{2}{*}{ B. cereus } & $0.683 \mathrm{~b}$ & $0.67 \mathrm{c}$ & $5.66 \mathrm{~b}$ & $0.648 \mathrm{~b}$ & $20.53 \mathrm{~b}$ & $20.23 \mathrm{~b}$ & $87.5 \mathrm{c}$ & $112.21 \mathrm{c}$ & $32.17 \mathrm{ab}$ & $37.76 \mathrm{~d}$ & $5.85 \mathrm{c}$ & $10.5 \mathrm{c}$ \\
\hline & $( \pm 0.03)$ & $( \pm 0.1)$ & $( \pm 0.04)$ & $( \pm 0.03)$ & $( \pm 0.47)$ & $( \pm 0.54)$ & $( \pm 2.22)$ & $( \pm 1.6)$ & $( \pm 0.11)$ & $( \pm 0.79)$ & $( \pm 0.18)$ & $( \pm 0.64)$ \\
\hline \multirow[t]{2}{*}{ P.moraviensis + tryp } & $0.786 \mathrm{a}$ & $0.772 \mathrm{a}$ & $6.26 \mathrm{a}$ & $0.781 \mathrm{a}$ & $25.43 \mathrm{a}$ & 23.31a & $103.7 \mathrm{a}$ & $121.56 \mathrm{a}$ & $38.97 \mathrm{a}$ & $45.45 \mathrm{a}$ & $6.31 \mathrm{a}$ & $12.7 \mathrm{~b}$ \\
\hline & $( \pm 0.06)$ & $( \pm 0.05)$ & $( \pm 0.04)$ & $( \pm 0.1)$ & $( \pm 0.43)$ & $( \pm 0.11)$ & $( \pm 5.48)$ & $( \pm 1.11)$ & $( \pm 0.47)$ & $( \pm 0.56)$ & $( \pm 0.19)$ & $( \pm 0.43)$ \\
\hline \multirow[t]{2}{*}{ B.cereus + tryp } & $0.807 \mathrm{a}$ & $0.733 \mathrm{~b}$ & $6.28 \mathrm{a}$ & $0.809 \mathrm{a}$ & $23.45 \mathrm{a}$ & $22.42 \mathrm{a}$ & $98.29 \mathrm{~b}$ & 124.49ab & $34.05 \mathrm{a}$ & $44.11 \mathrm{~b}$ & $6.36 \mathrm{a}$ & $12.922 \mathrm{a}$ \\
\hline & $( \pm 0.07)$ & $( \pm 0.07)$ & $( \pm 0.06)$ & $( \pm 0.08)$ & $( \pm 0.45)$ & $( \pm 0.56)$ & $( \pm 3.42)$ & $( \pm 1.18)$ & $( \pm 0.88)$ & $( \pm 0.43)$ & $( \pm 0.16)$ & $( \pm 0.93)$ \\
\hline \multirow[t]{2}{*}{ tryp } & $0.609 \mathrm{c}$ & $0.48 \mathrm{c}$ & $5.01 \mathrm{c}$ & $0.611 \mathrm{~b}$ & $20.24 \mathrm{~b}$ & $17.11 \mathrm{c}$ & $80.46 \mathrm{~d}$ & $106.58 \mathrm{c}$ & $28.48 \mathrm{c}$ & $30.1 \mathrm{~g}$ & $5.05 \mathrm{~d}$ & $8.28 \mathrm{~d}$ \\
\hline & $( \pm 0.04)$ & $( \pm 0.02)$ & $( \pm 0.09)$ & $( \pm 0.11)$ & $( \pm 0.24)$ & $( \pm 0.44)$ & $( \pm 6.66)$ & $( \pm 1.76)$ & $( \pm 0.78)$ & $( \pm 0.32)$ & $( \pm 0.14)$ & $( \pm 0.77)$ \\
\hline LSD & 0.59 & 0.99 & 2.11 & 1.44 & 3.09 & 2.98 & 1.39 & 1.72 & 3.31 & 2.88 & 1.23 & 1.09 \\
\hline
\end{tabular}

*= untreated uninoculated control, O.M= organic matter, P.moraviensis = Pseudomonas moraviensis, B.cerues = Bacillus cereus, tryp = tryptophan. Values followed by different letters are significantly at $(P<0.05)$. Values represented in parenthesis are standard error of means.

Table 2. Effects of PGPR application on leaves nutrients contents ( $\mathrm{mg} / \mathrm{kg})$. Measurements were made at After 57 DAS (2-3 leaf stage).

\begin{tabular}{ccccccc}
\hline Treatments & \multicolumn{2}{c}{ Ca } & \multicolumn{2}{c}{ K } & \multicolumn{2}{c}{ Mg } \\
\hline & Field & Pots & Field & Pots & Field & Pots \\
\hline control* $^{*}$ & $16.46 \mathrm{c}$ & $12.22 \mathrm{c}$ & $13.38 \mathrm{c}$ & $14.11 \mathrm{c}$ & $15.95 \mathrm{c}$ & $9.05 \mathrm{c}$ \\
& $( \pm 0.17)$ & $( \pm 0.78)$ & $( \pm 0.15)$ & $( \pm 0.66)$ & $( \pm 0.54)$ & $( \pm 0.98)$ \\
\hline P.moraviensis & $19.5 \mathrm{lb}$ & $15.63 \mathrm{~b}$ & $17.63 \mathrm{~b}$ & $21.21 \mathrm{~b}$ & $21.46 \mathrm{~b}$ & $13.23 \mathrm{~b}$ \\
& $( \pm 0.11)$ & $( \pm 0.92)$ & $( \pm 0.14)$ & $( \pm 0.44)$ & $( \pm 0.98)$ & $( \pm 0.65)$ \\
B. cereus & $19.9 \mathrm{~b}$ & $16.46 \mathrm{~b}$ & $18.77 \mathrm{~b}$ & $19.34 \mathrm{~b}$ & $20.54 \mathrm{~b}$ & $12.49 \mathrm{~b}$ \\
& $( \pm 0.14)$ & $( \pm 0.65)$ & $( \pm 0.12)$ & $( \pm 0.55)$ & $( \pm 0.13)$ & $( \pm 0.43)$ \\
\hline P.moraviensis + tryp & $22.09 \mathrm{a}$ & $19.13 \mathrm{a}$ & $19.14 \mathrm{a}$ & $25.56 \mathrm{a}$ & $22.67 \mathrm{a}$ & $14.81 \mathrm{a}$ \\
& $( \pm 0.12)$ & $( \pm 0.88)$ & $( \pm 0.41)$ & $( \pm 0.89)$ & $( \pm 0.33)$ & $( \pm 0.92)$ \\
B.cereus + tryp & $21.96 \mathrm{a}$ & $20.87 \mathrm{a}$ & $18.78 \mathrm{a}$ & $24.43 \mathrm{a}$ & $23.02 \mathrm{a}$ & $15.5 \mathrm{a}$ \\
& $( \pm 0.15)$ & $( \pm 0.56)$ & $( \pm 0.31)$ & $( \pm 1.11)$ & $( \pm 0.16)$ & $( \pm 1.02)$ \\
tryp & $16.86 \mathrm{e}$ & $13.88 \mathrm{c}$ & $13.48 \mathrm{c}$ & $14.33 \mathrm{c}$ & $16.24 \mathrm{c}$ & $10.06 \mathrm{c}$ \\
& $( \pm 0.18)$ & $( \pm 0.45)$ & $( \pm 0.36)$ & $( \pm 1.65)$ & $( \pm 0.14)$ & $( \pm 0.45)$ \\
\hline LSD & 3.33 & 4.41 & 2.97 & 5.09 & 2.22 & 4.67
\end{tabular}

*= untreated uninoculated control, P.moraviensis = Pseudomonas moraviensis, B.cerues = Bacillus cereus, tryp = tryptophan

Values followed by different letters are significantly at $(P<0.05)$. Values represented in parenthesis are standard error of means. 
Bacillus Cereus and Pseudomonas moraviensis improved the nutrient acquisition in treated wheat leaves in presence or absence of tryptophan. The $\mathrm{Ca}$ contents of leaves were increased by $18 \%$ in field and $28 \%$ in pots grown plants, following the treatment of Pseudomonas moraviensis and Bacillus cereus. Tryptophan addition further enhanced $\mathrm{Ca}$ by $19 \%$ and $37 \%$ in field and pots grown plants. Similarly the $\mathrm{K}$ contents of leaves were increased significantly (30\% and 50\%) in field and pots grown plants, and tryptophan addition further increased $\mathrm{K}$ contents by $15-20 \%$ both in pots and field grown plants. The $\mathrm{Mg}$ contents were increased by $30-40 \%$ when PGPR were applied singly, and with tryptophan further 15$20 \%$ higher $\mathrm{Mg}$ was observed. Nutrient availability and uptake is reported to be enhanced by PGPR in wheat. The higher accumulation of nutrients in treated leaves might be attributed to the PGPR proficiency in improving nutrient absorption and their translocation (Aslantas et al., 2007).

\subsection{Wheat growth}

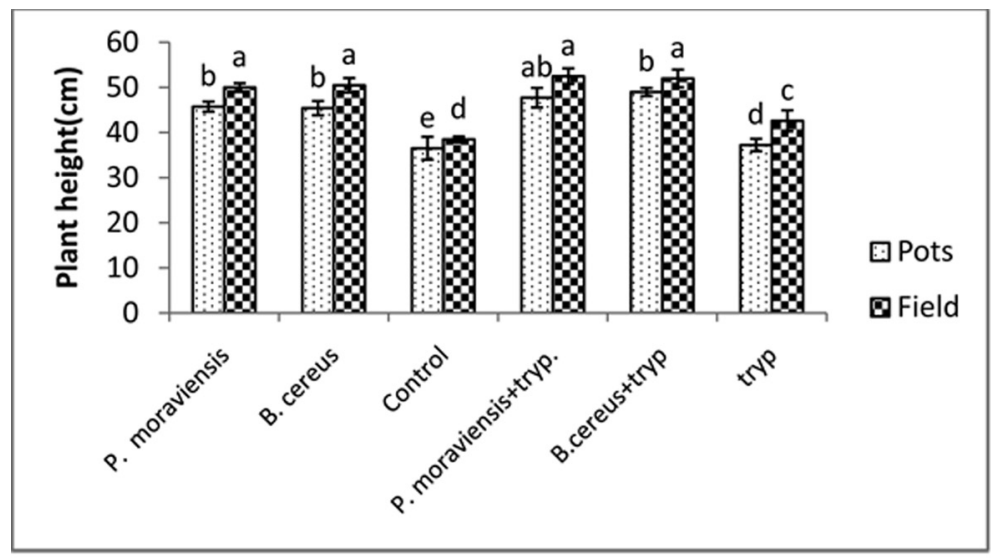

Figure 1. Plant height $(\mathrm{cm})$ treated with Pseudomonas moraviensis and Bacillus cereus alone and in addition with tryptophan. Control $=$ untreated uninoculated plants, P.moraviensis $=$ Pseudomonas moraviensis, B.cerues $=$ Bacillus cereus and tryp= tryptophan alone. Values given are mean of four replicates \pm SE. Values followed by different letters heading the bars are significantly different $(P<0.05)$.

Both Pseudomonas moraviensis and Bacillus cereus increased plant height (Figure 1) in pots and field. Inoculation of Pseudomonas moraviensis increased the plant height of wheat grown in pots and field by $32 \%$ and $25 \%$ respectively. Tryptophan addition with Pseudomonas moraviensis further increased plant height by $4 \%$ and $9 \%$ in field and pots grown plants respectively. Similarly, Bacillus cereus increased plant height by $31 \%$ and $23 \%$ and further $4 \%$ and $7 \%$ increase was observed in pots and field grown plants in the presence of tryptophan. The evidenced increase in plant height of inoculated wheat in the presence of tryptophan and PGPR attributed the enhanced IAA availability, which induce cell division and cell elongation. The readily available tryptophan in treated plants is converted into IAA, thereby improving plant height as documented previously (Mohite, 2013). 


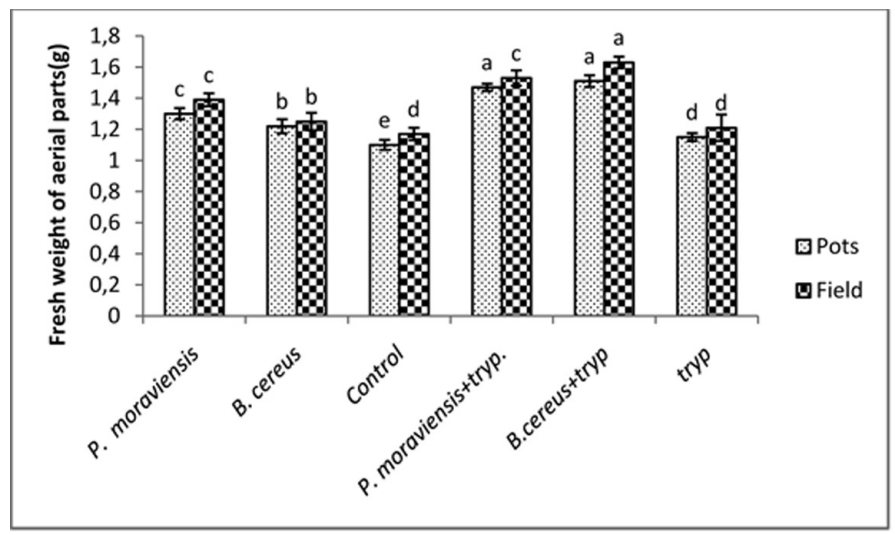

Figure 2. Fresh weight (g) of aerial parts of single plant treated with Pseudomonas moraviensis and Bacillus cereus alone and with tryptophan. Control= untreated uninoculated plants, P.moraviensis $=$ Pseudomonas moraviensis, B.cerues $=$ Bacillus cereus and tryp $=$ tryptophan alone. Values given are mean of four replicates $\pm \mathrm{SE}$. Values followed by different letters heading the bars are significantly different $(P<0.05)$.

The Pseudomonas moraviensis increased the fresh weight (Figure 2) by $19 \%$ and $18 \%$ in field and pots respectively. Addition of tryptophan further increased $11 \%$ fresh weight in field and $16 \%$ in pots. Bacillus cereus application with tryptophan exhibited 30-35\% over control. The observed increase in fresh weight may be attributed to IAA induced water, nutrient uptake, and proliferation of root system (Mohite, 2013). Increase in plant height and fresh weight of PGPR treated plants, in the presence or absence of tryptophan also insinuate toward the role of PGPR in enhancing nutrients availability as well as improved organic matter in the soil (Sasirekha et al., 2012).

\subsection{Wheat physiology}

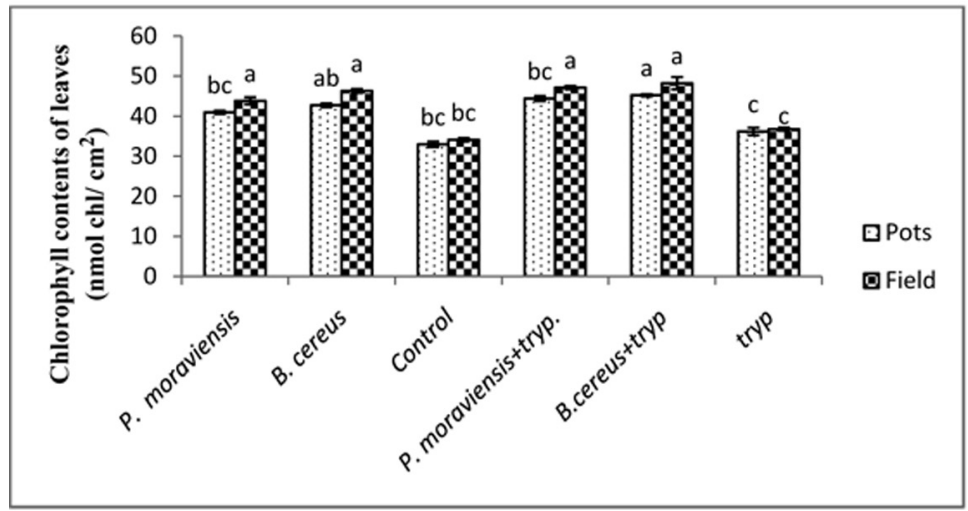

Figure 3. Chlorophyll contents (nmolchl/ $\mathrm{cm}^{2}$ ) of leaves treated with Pseudomonas moraviensis and Bacillus cereus alone and with tryptophan. Control= untreated uninoculated plants, $P$. moraviensis $=$ Pseudomonas moraviensis, B.cerues $=$ Bacillus cereus andtryp $=$ tryptophan alone. Values given are mean of four replicates \pm SE. Values followed by different letters heading the bars are significantly different $(P<0.05)$. 
Inoculation with Pseudomonas moraviensis increased chlorophyll contents (Figure 3 ) equally $24-26 \%$ in pots and field. Addition of tryptophan with Pseudomonas moraviensis further increased $8-12 \%$ chlorophyll contents both in pots and field. Bacillus cereus exhibited significantly higher (26-35\%) chlorophyll content in pots and field. Addition of tryptophan with Bacillus cereus further increased $11 \%$ chlorophyll in field and $8 \%$ in pots. The improved chlorophyll contents might be attributed to the ability of associated PGPR, residing there in to assist water and mineral absorption (Bashan et al., 2004).

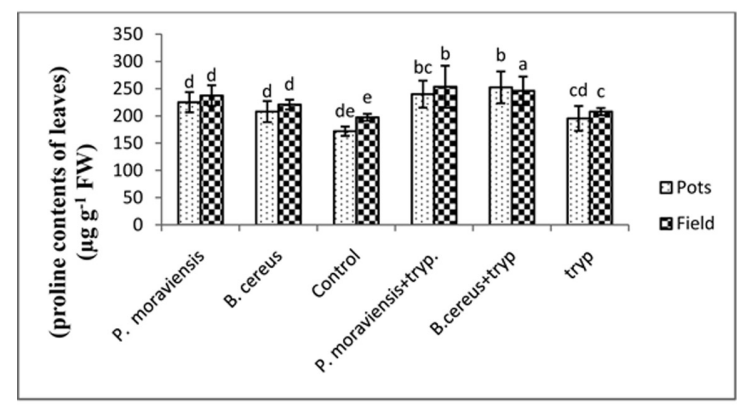

Figure 4. Proline.contents of leaves $\left(\mu \mathbf{g ~ g}^{-1}\right)$ of leaves treated with Pseudomonas moraviensis and Bacillus cereus alone and with tryptophan. ontrol= untreated uninoculated plants, $P$ moraviensis $=$ Pseudomonas moraviensis, B.cerues $=$ Bacillus cereus andtryp= tryptophan alone. Values given are mean of four replicates with \pm SE. Values followed by different letters heading the bars are significantly different $(P<0.05)$.

Pseudomonas moraviensis increased proline contents by $17 \%$ in field and $31 \%$ in pots. Addition of tryptophan with Pseudomonas moraviensis further increased the proline contents of plants by $8-10 \%$ both in pots and field. Bacillus cereus increased proline content by $12 \%$ and $21 \%$ over control in pots and field respectively. This increase was $24 \%$ and $49 \%$ in Bacillus cereus + tryp treatment. The observed increase in chlorophyll and proline contents reflects the role of PGPR in stomatal conductance, osmoregulation, and photosynthesis (Prado et al., 2000). Proline acts as a source of organic nitrogen reserve, osmoprotectant and antioxidant under stress and PGPR application imparted stimulatory effects on proline accumulation (Ali et al, 2013).

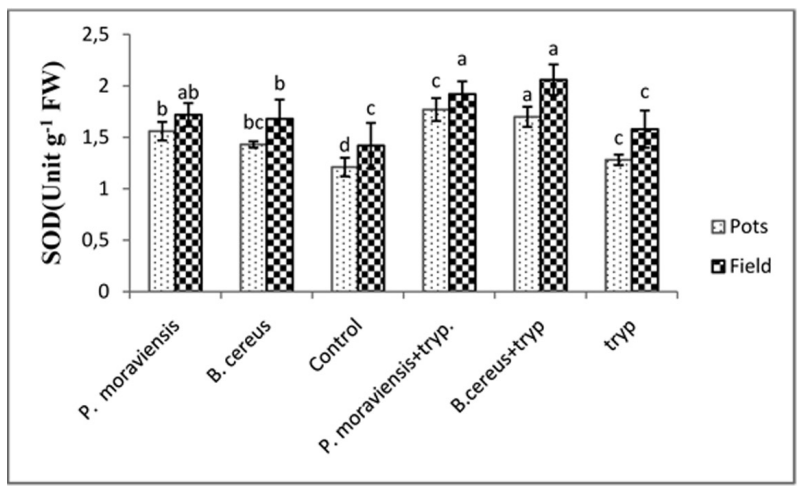

Figure 5. SOD activity (unit $\mathrm{g}^{-1} \mathrm{FW}$ ) of leaves treated with Pseudomonas moraviensis and Bacillus cereus alone and with tryptophan. Control= untreated uninoculated plants, $P$.moraviensis = Pseudomonas moraviensis, B.cerues =Bacillus cereus andtryp=tryptophan alone. Values given are mean of four replicates with $\pm \mathrm{SE}$. Values followed by different letters heading the bars are significantly different $(P<0.05)$. 


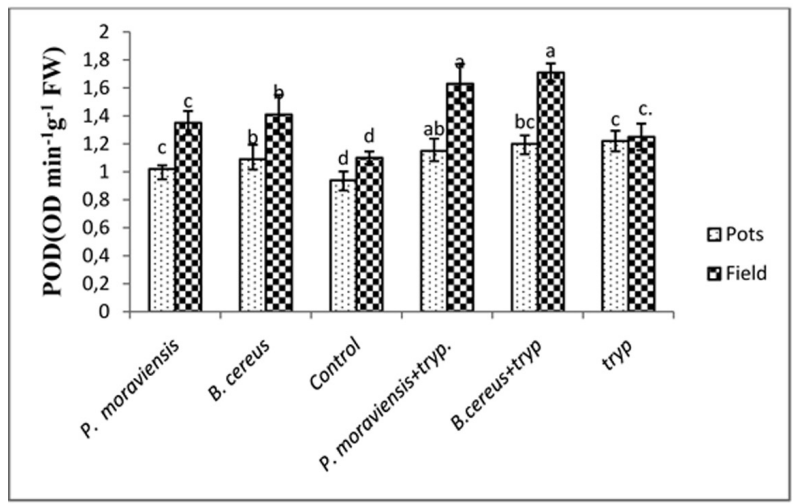

Figure 6. POD activity (OD min $^{-1} \mathbf{g}^{-1} \mathbf{F W}$ ) of leaves treated with Pseudomonas moraviensis and Bacillus cereus alone and with tryptophan. Control= untreated uninoculated plants, $P$.moraviensis $=$ Pseudomonas moraviensis, B.cerues $=$ Bacillus cereus andtryp $=$ tryptophan alone. Values given are mean of four replicates with $\pm \mathrm{SE}$. Values followed by different letters heading the bars are significantly different $(P<0.05)$.

Plants treated with Pseudomonas moraviensis showed $20 \%$ higher SOD (Figure 5) and POD (Figure 6) activities in field. This increase was $29 \%$ and $9 \%$ higher over control in pots grown plants. In the presence of tryptophan Pseudomonas moraviensis exhibited further 14\% higher SOD and $26 \%$ higher POD activity in field, and $17 \%$ and $13 \%$ in pots. Bacillus cereus showed $11 \%$ higher SOD and
$28 \%$ higher POD in field and $18 \%$ in pots respectively. Addition of tryptophan exhibited further 27\% higher SOD and 34\% higher POD activities in field. The increase in SOD and POD was $22 \%$ and $12 \%$ over control in pots. The observed increase in antioxidant activities, may be attributed to the positive role of PGPR on detoxification of reactive oxygen species (Faize and Burgos, 2011).

\subsection{Wheat yield}

Table 3. Effects of PGPR application on yield parameters of wheat at maturity. Measurements were made at 159 DAS.

\begin{tabular}{|c|c|c|c|c|c|c|c|c|}
\hline \multirow[t]{2}{*}{ Treatments } & \multicolumn{2}{|c|}{ Plants $/ \mathrm{m}^{2}$} & \multicolumn{2}{|c|}{$\begin{array}{l}\text { spike length } \\
\text { (cm) }\end{array}$} & \multicolumn{2}{|c|}{ seeds/spike } & \multicolumn{2}{|c|}{$\begin{array}{l}\text { seeds weight } \\
\text { (g) }\end{array}$} \\
\hline & Field & Pots & Field & Pots & Field & Pots & Field & Pots \\
\hline \multirow[t]{2}{*}{ control* } & $222.5 b$ & -- & $5.2 \mathrm{c}$ & $4.4 \mathrm{c}$ & $39 \mathrm{~b}$ & $25.25 \mathrm{e}$ & $39.67 \mathrm{~b}$ & $37.23 \mathrm{~b}$ \\
\hline & $( \pm 7.94)$ &.- & $( \pm 0.11)$ & $( \pm 0.16)$ & $( \pm 3.45)$ & $( \pm 3.73)$ & $( \pm 1.24)$ & $( \pm 0.95)$ \\
\hline \multirow[t]{2}{*}{ P.moraviensis } & $239.25 b$ & -- & $6 \mathrm{a}$ & $5.2 \mathrm{ab}$ & $45.75 \mathrm{a}$ & $32.25 \mathrm{c}$ & $50.76 \mathrm{a}$ & $43.19 \mathrm{a}$ \\
\hline & $( \pm 6.09)$ & - & $( \pm 0.15)$ & $( \pm 0.1)$ & $( \pm 0.85)$ & $( \pm 3.5)$ & $( \pm 0.79)$ & $( \pm 0.63)$ \\
\hline \multirow[t]{2}{*}{ B. cereus } & $242.75 \mathrm{bb}$ & -- & $6.2 \mathrm{a}$ & $5.5 \mathrm{~b}$ & $46.25 \mathrm{a}$ & $33.75 \mathrm{c}$ & $50.2 \mathrm{a}$ & $44 a$ \\
\hline & $( \pm 6.29)$ &.- & $( \pm .09)$ & $( \pm 0.23)$ & $( \pm 1.93)$ & $( \pm 1.93)$ & $( \pm 1.23)$ & $( \pm 2.32 \mathrm{~b})$ \\
\hline \multirow[t]{2}{*}{ P.moraviensis + tryp } & $336 \mathrm{a}$ & -- & $6.52 \mathrm{a}$ & $5.9 \mathrm{~b}$ & $49.25 \mathrm{a}$ & $35.75 b$ & $51.42 \mathrm{a}$ & $46.5 \mathrm{a}$ \\
\hline & $( \pm 9.5)$ & -- & $( \pm .35)$ & $( \pm 0.12)$ & $( \pm 2.49)$ & $( \pm 2.48)$ & $( \pm 1.37)$ & $( \pm 1.08)$ \\
\hline \multirow[t]{2}{*}{ B.cereus + tryp } & $289.5 \mathrm{a}$ & -- & $6.47 \mathrm{a}$ & $6.1 \mathrm{a}$ & $48.5 \mathrm{a}$ & $37 \mathrm{~b}$ & $53.42 \mathrm{a}$ & $45 \mathrm{a}$ \\
\hline & $( \pm 5.21)$ & -- & $( \pm 0.22)$ & $( \pm 0.11)$ & $( \pm 3.23)$ & $( \pm 2.87)$ & $( \pm 1.93)$ & $( \pm 1.49)$ \\
\hline \multirow[t]{2}{*}{ tryp } & $232 \mathrm{~b}$ & -- & $5.5 \mathrm{~b}$ & $4.32 \mathrm{bc}$ & $42.75 \mathrm{~b}$ & $30.25 \mathrm{~d}$ & $40.29 \mathrm{~b}$ & $39.21 \mathrm{~b}$ \\
\hline & $( \pm 6.63)$ &.- & $( \pm 0.18)$ & $( \pm 0.19)$ & $( \pm 1.41)$ & $( \pm 3.86)$ & $( \pm 1.75)$ & $( \pm 0.28)$ \\
\hline LSD & 7.32 & & 1.65 & 2.21 & 3.92 & 4.34 & 5.55 & 2.29 \\
\hline
\end{tabular}

*= untreated uninoculated control, P.moraviensis = Pseudomonas moraviensis, B.cerues = Bacillus cereus, tryp = tryptophan. Values followed by different letters are significantly at $(P<0.05)$. Values represented in parenthesis are standard error of means. 
Pseudomonas moraviensis and Bacillus cereus application with tryptophan exhibited $30 \%$ more plants/ $\mathrm{m}^{2}$ (Table 3) over control. Increase in spike length of wheat treated with PGPR was $18 \%$ and $25 \%$ in field and pots grown plants. Addition of tryptophan with Bacillus cereus, further increased $10-14 \%$ higher spike length over control both in pots and field grown plants. Similarly, Pseudomonas moraviensis increased $15 \%$ seeds/spike and $22 \%$ seed weight in field, and $28 \%$ and $16 \%$ in pots. This increase was higher $(11 \%$ and $20 \%$ ) in pots and field grown plants when tryptophan was added with Pseudomonas moraviensis.

Bacillus cereus produced $18 \%$ more seeds /spike and $21 \%$ more seed weight in field and $29 \%$ and $19 \%$ in pots. Addition of tryptophan with Bacillus cereus further increased $10 \%$ seed/spike and seed weight both in pots and field. Increase in spike length, grain yield and seed weight might be attributed to increase level of N, P and $\mathrm{K}$ in the presence of PGPR and tryptophan (Shaharoona et al., 2008). Addition of tryptophan stimulates the activities and efficiency of PGPR in the soil, by improving the ability to produce phytohormones (Spaepan et al., 2011). The higher observed increase in yield components might be attributed to the greater microbial and enzymatic activities and rapid release of the nutrients in the soil (Gryndler et al., 2008).

\section{Conclusions}

This study revealed the positive role of Bacillus cereus and Pseudomonas moraviensis, on wheat, when used as bioinoculants. Single inoculation of both strains, comprehensively increased the growth and improved the physiology of treated plants. Tryptophan addition further augmented these effects in sterilized pot or field condition. The tryptophan addition, may help the applied PGPR to improve their IAA production, and would be helpful in strengthening wheat physiology. Though, it is documented previously that different bacterial strains have different capability for utilization of tryptophan, but this study emphasized the distinctive role of tryptophan application under field condition. Bacillus cereus was found to be more effective than Pseudomonas moraviensis, either in the presence or absence of tryptophan. The exploration of such beneficial bacterial strain, and their use as biofertilizer in different agroclimatic regions could be handful in sustainable agriculture.

\section{Acknowledgement}

The authors are thankful to Higher Education Commission (HEC) of Pakistan for providing financial support for research.

\section{References}

Abbas, S.H., Sohail, M., Saleem, M., Tariq, M., Aziz, I.,Qammar, M., Majeed, A., Arif, M. 2013. Effects of L-Tryptophan on plant weight and pod weight in chickpea under rainfed conditions. Sci. Tech. Dev. 32(4), 277-280.

Ali, M.H., Siddiqui, M.H., Al-wahibi, M.H., Basalah, M.O., Sakran A.M., and El-Zaidy, M. 2013. Effect of proline and Abscisic acid on growth and physiological performance of Faba bean under water stress. Pak. J. Bot. 45(3), 933-940.

Aslantas, R., Cakmakci, R., Sahin, F. 2007. Effect of plant growth promoting rhizobacteria on young apples trees growth and fruit yield under orchard conditions. Sci. Hort. 111(4), 371-377.

Bashan, Y., Holguin, G., De-Bashan, L.E. 2004. Azospirillum- plant relationships: physiological, molecular, agricultural and environmental advances. Can. J. Microbiol. 50, 521-577. 
Beauchamp, C., Fridovich, I. 1971. Superoxide dismutase: improved assay and ansassay applicable to acrylamide gels. Anal.Biochem. 44, 276-287.

Bates, L.S., Waldern, R.P., Teare, I.D. 1973. Rapid determination of free proline for water status studies, Plant Soil. 39, 205-207.

Faize, M.L., Burgos, L. 2011.Involvement of cytosolic ascorbate peroxidase and $\mathrm{Cu} / \mathrm{Zn}$-superoxide dismutase for improved tolerance against drought stress. J. Exp. Bot. 62(8), 2599-2613.

Gryndler, M., Sudova, R., Rydlova, J. 2008. Cultivation of high biomass crops on mine spoil banks: Can microbial inoculation compensate for high doses of organic matter? Bioresource. Technol. 99, 6391-6399.

Hayyat, R., Khalidi, R., Ehsani, M., Ahmed I., Yokota, A., Ali, S. 2013.Molecular characterization of soil bacteria for improving crop yield in Pakistan. Pak. J. Bot. 45(3), 1045-1055.

Idris, E., Bochow, E.S., Ross, H., Borriss, R. 2004. Use of Bacillus subtilis as biocontrol agent. VI. Phytohormone like action of culture filtrates prepared from plant growth-promoting Bacillus amyloliquefaciensFZB24, FZB42, FZB45 and Bacillus subtilis FZB37, J. Plant Dis. Prot. 111, 583-590.

Mehnaz, S., Weselowski, B., Aftab, F., Zahid, S., Lazarovits, G., Iqbal, J. 2009. Isolation, characterization, and effect of fluorescent pseudomonads on micropropagated sugarcane. Canad. J. micro. 55( 8), 1007-1011.

McKeague, J.A. 1978. Manual on soil sampling and methods of analysis, (ED) Canadian Society of Soil Science, 66-68.

McLean, E.O. 1982. Soil pH and lime requirement. In: A.L Page,. Miller A.L, Keeney DR (eds) Methods of soil analysis. Part 2. Agron.Monogr. 9, Am. Soc. Agron., Madison, WI, 199-223.
Minaxi, J., Saxena, S., Chandra., Nain, L. 2013. Synergistic effect of phosphate solubilizing rhizobacteria and arbuscularmycorrhiza on growth and yield of wheat plants. J. Soil. Sci. Plant. Nutr. 13 (2), 511-525.

Mohite, B. 2013. Isolation and characterization of indole acetic acid (IAA) producing bacteria from rhizospheric soil and its effect on plant growth. J. Soil Sci. Plant Nutr. 13(3), 638-649.

Patten, C., Glick B.R., 1996. Bacterial biosynthesis of indole-3- acetic acid. Canad. J. Micro. 42, 207 220.

Prado, F.E., Boero, C., Gallardo, M., Gonzalez, A., 2000. Effect of $\mathrm{NaCl}$ on germination, growth, and soluble sugar content in Chenopodium quinoa Willd.Seeds. Bot. Bull. Acad. Sin. 41, 27-34.

Rani, M.U., Arundhathi., Reddy, G. 2011. Bacillus cereus and Enterobacter cancerogenus screened for their efficient plant growth promoting traits rhizobacteria (PGPR) and antagonistic traits among sixteen bacterial isolates from rhizospheric soils of Pigeon Pea. Afr. J. Micro. Res. 5(15), 2090-2094.

Reitemeier., R.F. 1943. Semi microanalysis of saline soil solutions. Indus.And Engin.Chem. Analyt. $15,393-402$.

Rosas, S.B., Avanzin, G., Carlier, E., Pasluosta, C., Pastor, N., Rovera, M. 2009. Root colonization and growth promotion of wheat and maize by Pseudomonas aurantiaca SR1. Soil. Biol. Biochem. 41, 1802-1808.

Sasirekha, B., Shivakumar, S., Sullia, S.B. 2012. Statistical optimization for improved indole-3acetic acid (IAA) production by Pseudomonas aeruginosa and demonstration of enhanced plant growth promotion. J. Soil Sci. Plant Nutr. 12(4), 863-873 
Schoebitz, M., Ceballos ,C., Ciampi, L. 2013. Effect of immobilized phosphate solubilizing bacteria on wheat growth and phosphate uptake. J. Soil Sci. Plant Nutr.13 (1), 1-10

Shaharoona, B., Naveed, M., Arshad, M., Zahir, Z.A. 2008. Fertilizer dependent efficiency of Pseudomonas for improving growth, yield, and nutrient use efficiency of wheat (Triticumaestivum L.). Appl. Micro. Biotech. 79, 147-155.

Tsavkelova, E.A., Cherdyntseva, T.A., Klimova, S.Y., Shestakov, A.I., Botina, S.G., Netrusov, A.I. 2007. Orchid-associated bacteria produce indole-3-acetic acid, promote seed germination, and increase their microbial yield in response to exogenous auxin. Arch. Micro. 188 (6), 655-664.

Vetter, J. L., Steinberrg, M.P., Nelson, A.I. 1958. Quantitive Determination of peroxidase in sweet corn. J. Agri.Food. Chem. 6, 39-41.

Villareal, S.Q., Hernández, N.Z., Romero, I.L., Lazcano, E.A., Dorantes, A.R. 2012. Assessment of plant growth promotion by rhizobacteria supplied with tryptophan as phytohormone production elicitor on Axonopus affinis. Agri. Sci. Res. J. 2(11), 574- 580.
Wachowska ,U., Okorski, A., Głowacka, K. 2006. Population structure of microorganisms colonizing the soil environment of winter wheat. Plant.Soil Envir. 52, 39-44.

Walkley, A., Black, I.A. 1934. An examination of degtiareff method for determining soil organic matter and a proposed modification of chromic acid titration method.Soil. Sci. 37, 29-37.

Weisberg, W.G., Barns, S.M., Pelletier, B.A., Lane, D.J. 1991. 16S ribosomal DNA amplification for phylogenetic study. J. Bacteriol. 173, 697-703.

Yadav, S., Shivani, Yadav, S., Kaushik, R., Anil, K., Saxena, K., Arora, D.K. 2013. Genetic and functional diversity of fluorescent Pseudomonas from rhizospheric soils of wheat crop. J. Basic. Microbiol. 1-13.

Zhao, L., Xu, R., Sun, R., Deng, Z., Yang, W., Wei, G. 2011. Identification and characterization of the endophytic plant growth prompter Bacillus cereus strain MQ 23 isolated from sophora alopecuroides root nodules. Brazilian. J. Micro. 2, 567-575. 